\title{
FACTORS INFLUENCING THE ADOPTION OF E-TILANG; EMPIRICAL EVIDENCE FROM THE UTAUT MODEL
}

\author{
Eva Yumami ${ }^{1}$, Djoko Budiyanto Setyohadi ${ }^{2}$, Suyoto ${ }^{3}$ \\ 1,2,3 Universitas Atma Jaya Yogyakarta, Yogyakarta, Indonesia \\ evayumami2015@gmail.com ${ }^{1}$, djoko@mail.uajy.ac.id ${ }^{2}$, suyoto@staff.uajy.ac.id ${ }^{3}$
}

\begin{abstract}
Mid-year 2017 The National Police of the Republic of Indonesia publishes e-tilang technology innovation. Traffic police use e-tilang in handling vehicles that violate traffic on the highway. This is to improve service to the public. This research factor influences acceptance and use of e-tilang by using UTAUT model. This research was conducted in Bengkulu area with 152 traffic policemen. The findings of this study indicate that effort expectancy, performance expectancy, and social influences positively affect the use of e-tilang. Furthermore, no positive effect on the intention of using e-tilang is the Facilitation Conditions. The results of this study are important steps to improve e-tilang services.
\end{abstract}

Keywords: E-tilang, Information System, Innovation Technology, UTAUT.

\section{Introduction}

Currently, the development of information technology in the government is growing rapidly. This is particularly important given the potential to improve services, reduce costs and accessibility to citizens (Carter \& Bélanger 2005). E-government provides certain benefits of society transparency in government processes, efficient services will reduce costs and time. E-government for government helps simplify procedures, improve office management and create effective government regulations (Kayani et al. 2011).

In mid-2017, the State Police of the Republic of Indonesia issued e-tilang innovation technology. E-tilang is an online application used by traffic police. E-tilang aims to improve service to the public and reduce the misuse of payment of fines to
Original Scientific Paper doi:10.5937/jouproman6-16650

traffic police on the highway. Traffic policemen are responsible for ensuring that traffic rules are adhered to by vehicle drivers (Bates et al. 2017; Bates et al. 2014). E-tilang reflects the strategy of the traffic police in delivering information and communications to the public. This is in line with Lindsay et al. (2011) study, which states that $72 \%$ of technology can help police work and be able to solve problems.

This study uses a model reference Venkatesh et al. (2003). The model used in evaluating the acceptance and application of technology. Unified Theory Acceptance and Use of the Technology (UTAUT) is able to explain behavioral intentions in using system information. UTAUT explains the intent and behavior of users in using system information. Performance Expectations, Business Expectations, Social Influence, and facilitating conditions have a direct effect on the intentions of using the system. This model describes the intent of the user in using the system information and behavior of its users.

The Performance Expectations, Effort Expectations, Social Influence, and Facilitation Conditions have a direct effect on behavioral intentions in UTAUT. These four constructs are used to measure from eGovernment services at present. The linkage between the main constructs at UTAUT shows a high significance of technology acceptance. 
Based on the above explanation, the researcher will identify the factors influencing the use and acceptance of e-tilang at traffic police by using the UTAUT method. This research will be useful for developing additional literature based on current conceptual data and future research in Indonesia and its territory. The findings of this research can be a consideration to improve information technology services in the police.

\section{Literature Review}

According to Alshehri, his research investigates the feasibility of UTAUT for the use of technology received in government (Alshehri 2012). The findings indicate UTAUT is eligible for use on e-government acceptance. Increasing use and acceptance of e-government especially in the service to the community makes the service easier and faster. Information technology affects the ability of police to solve problems. Legohérel (2013) said the use of new technologies can improve performance. Lau (2016), explains that performance expectancy greatly influences behavioral intentions to use technology. Effort expectancy explains the ease of service in e-government. Effort expectancy has the effect on behavioral intentions in using technology. Social influences can convince each other that it is easy to accept the use of technology. Facilitating conditions is a picture of infrastructure and technical support for the system used within the organization, this is like previous studies (Akhtar Shareef et al. 2014; Lin et al. 2010).

\section{Research Model and Hypothesis}

This method UTAUT is composite of Theory Reasoned Action, Planned Behavior Theory (Ajzen 1991), Technology Acceptance Model, Diffusion of Innovation Model, (Mustonen-Ollila \& Lyytinen 2003) and TAM2 (Madden et al. 1992). The strength of this model is widely used in various studies and applies it extensively to various technologies (Williams et al. 2015). The UTAUT model consists of 4 variables, that is performance expectancy, effort expectancy, social influence, facilitation conditions. According to Lin et al. (2010), the variable will be an important role as a direct determinant of usage behavior. In this study, performance expectations, social influence, effort expectations, and facilitation conditions are the main constructs that will be the effect on Behavioral Intention. Based on the UTAUT model, it can be estimated that this key factor influences the adoption of e-tilang. The linkages between major constructs at UTAUT have demonstrated a high significance of technology acceptance and have been shown to be consistent with many studies (Azam 2015, Raja Yusof et al. 2017). The UTAUT model as shown in figure 1.

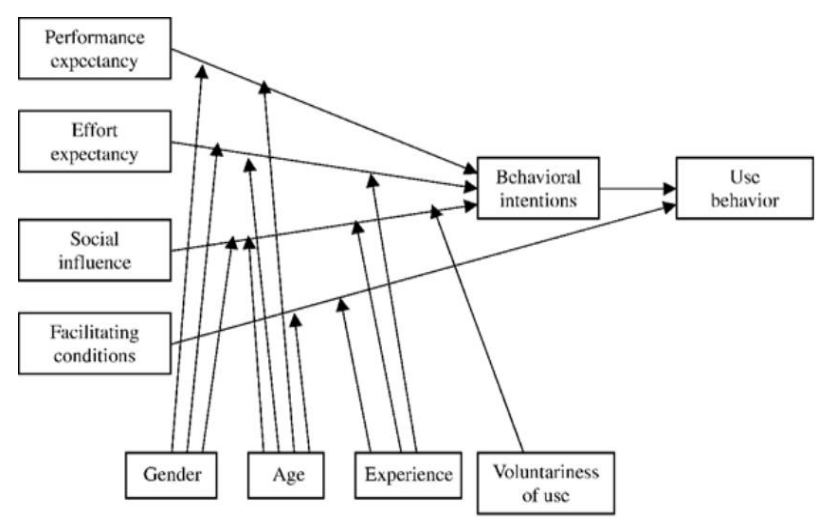

Figure 1. UTAUT Model

Rahman et al (2014) used UTAUT's main variable in evaluating the acceptance of smart boards among school teachers. This is in line with research on the acceptance of new etilang technology. The research model is shown in Figure 2. 


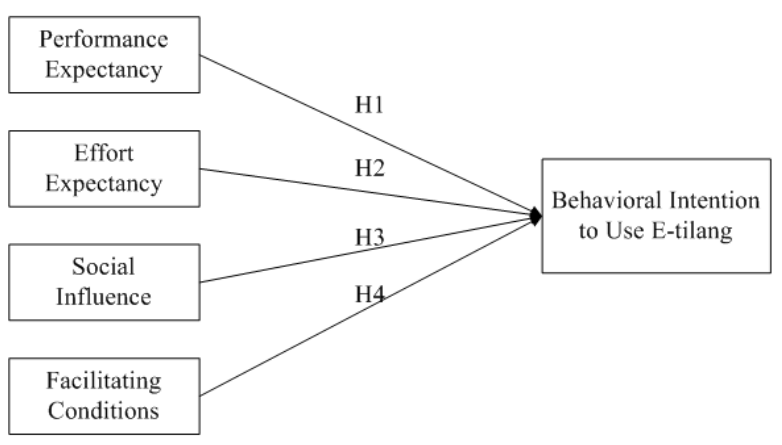

Figure 2. Model of Research

An insight into established research suggests that the model has been empirically tested for studies of e-government adoption. Empirically this study is the most widely used and applied adoption and acceptance model, using e-government services can provide useful insights and implications for understanding someone's intentions (Barua 2012).

Performance expectations are one of UTAUT constructions, performance expectations explain how much one believes that information systems can help the work to get the desired results (Venkatesh et al. 2003). This performance expectancy is derived from a combination of the concept benefit perception, extrinsic motivation, occupational conformance, relative profit, and expected outcomes. Performance expectancy makes it possible to access information quickly and conveniently. performance expectancy greatly affects the user's intentions (Lau 2016). The hypotheses are summarized as follows:

H1: Performance Expectancy positively influences behavioral intentions in using etilang.

Effort expectancy describes the level of ease of using the system. Effort expectancy is a combination of TAM 2 and MPCU methods. Effort Expectancy explains the ease of service e-tilang, how users interact with the interface. This construction is like that of Williams et al. (2015) that influenced users' attitudes toward usage. The hypotheses are summarized as follows:
H2: Effort Expectancy positively influences behavioral intentions in using e-tilang.

The Social Effect is the UTAUT construct that explains how much one be sure lest employ a new system can minimize effort in work. This construct describes the person's ease or environment to influence each other. The hypotheses are summarized as follows:

H3: Social Influence positively influences behavioral intentions in using e-tilang.

Facilitating conditions are how much one believes that the existence of a good organizational and technic infrastructure could support the employ from the system. Facilitating conditions is a very important service to the organization. The hypotheses are summarized as follows:

H4: Facilitating Conditions positively affects behavioral intentions in using e-tilang.

\section{Research Methods}

Case studies in this research are traffic police in Bengkulu area. The number of traffic police respondents is 165 personnel. The survey was conducted using a questionnaire given to all traffic police. Based on Kumar (2016), the questionnaire was distributed with probability sampling technique. Determination of the number of respondents refers to previous studies (Chang, 2013) and is based on MacCallum et al (MacCallum et al. 1996). Another consideration is that in SEM, a sample size of 100-200 is required for sample size determination.

SEM techniques allow researchers to evaluate the construction model and to estimate the structural relationship between latent variables simultaneously (Hair et al., 2006). The data were tested using Structural Equation Modeling (SEM) with the help of AMOS 22 devices. Researchers collected data through 165 questionnaires and 152 returned, with a response rate of $87.36 \%$. The questionnaire used was 165 and returned as many as 152 questionnaires, with a response rate of $87.36 \%$. Respondent's demographics the results are shown in table 1. 
Table 1: Demographic Data $(\mathrm{N}=152)$

\begin{tabular}{|l|l|r|r|}
\hline Character & Frequency & Percent \\
\hline \multirow{4}{*}{ Gender } & Male & 133 & 87.5 \\
\cline { 2 - 4 } & Female & 19 & 12.5 \\
\hline \multirow{4}{*}{ Age } & Less than 25 & 23 & 15.13 \\
\cline { 2 - 4 } & $26-30$ & 31 & 20.39 \\
\cline { 2 - 4 } & $31-35$ & 92 & 60.53 \\
\cline { 2 - 4 } & More than 36 & 6 & 3.95 \\
\hline \multirow{2}{*}{$\begin{array}{l}\text { Educational } \\
\text { Level }\end{array}$} & High school & 132 & 86.84 \\
\cline { 2 - 4 } & Bachelor & 17 & 11.18 \\
\cline { 2 - 4 } $\begin{array}{l}\text { Internet } \\
\text { Experience }\end{array}$ & Master & 3 & 1.98 \\
\hline \multirow{4}{*}{$\begin{array}{l}\text { E-tilang } \\
\text { Usage }\end{array}$} & Experienced & 150 & 98.68 \\
\cline { 2 - 4 } & $\begin{array}{l}\text { Less than } 1 \\
\text { month }\end{array}$ & 19 & 1.32 \\
\cline { 2 - 4 } & $1-3$ month & 27 & 12.5 \\
\cline { 2 - 4 } & $\begin{array}{l}\text { More than } 3 \\
\text { months }\end{array}$ & 106 & 69.74 \\
\hline
\end{tabular}

\section{Data Analysis}

A. Measurement Model

Test the validity and reliability of the software used Amos 22. The value of reliability that qualifies if the average value of the AVE and loading factor values greater than 0.5. Furthermore, the $\mathrm{CR}$ value must be greater than the AVE value (Hair et al, 2006). Based on the calculation, the value of AVE for each construct is $0.636,0.639,0.655,0.565$ and 0.568 . While the value of CR is $0.898,0.904$, $0.866,0.867$ and 0.891 . This shows that the value of $A V E$ and $C R$ value has met the recommended value of 0.5 and shows a good reliability test. The results are shown in table 2.

Table 2. Factor loading, AVE, and CR

\begin{tabular}{|l|l|r|r|c|}
\hline \multicolumn{1}{|c|}{ Variable } & Items & $\begin{array}{c}\text { Factor } \\
\text { Loading }\end{array}$ & AVE & CR \\
\hline Performance & PE 1 & 0.803 & 0.6364 & 0.8982 \\
Expectancy & PE 2 & 0.701 & & \\
& PE 3 & 0.807 & & \\
& PE 4 & 0.876 & & \\
& PE 5 & 0.802 & & \\
\hline
\end{tabular}

\begin{tabular}{|l|l|r|l|l|}
\hline Effort & EE 1 & 0.874 & 0.6396 & 0.9045 \\
Expectancy & EE 2 & 0.713 & & \\
& EE 3 & 0.815 & & \\
& EE 4 & 0.791 & & \\
& EE 5 & 0.846 & & \\
\hline Social & SI 1 & 0.732 & 0.6555 & 0.8664 \\
Influence & SI 2 & 0.709 & & \\
& SI 3 & 0.798 & & \\
& SI 4 & 0.806 & & \\
& SI 5 & 0.709 & & \\
\hline Facilitating & FC 1 & 0.756 & 0.5655 & 0.8677 \\
Conditions & FC 2 & 0.719 & & \\
& FC 3 & 0.826 & & \\
& FC 4 & 0.759 & & \\
& FC 5 & 0.703 & & \\
\hline Behavioral & BI 1 & 0.831 & 0.5682 & 0.8971 \\
Intention & BI 2 & 0.8 & & \\
& BI 3 & 0.794 & & \\
& BI 4 & 0.712 & & \\
& BI 5 & 0.845 & & \\
\hline
\end{tabular}

B. Discriminant Validity Test

Discriminant validity is a different measure than others. This test was conducted to measure whether two different factors, yielding valid data on to the AVE square root ratios and available factors (Barua 2012), shown in Table 3.

Table 3. Discriminant validity

\begin{tabular}{|c|c|c|c|c|c|}
\hline \multicolumn{7}{|c|}{ DISCRIMINANT VALIDITY } \\
\hline & PE & EE & SI & FC & BI \\
\hline PE & 0.7998 & & & & \\
\hline EE & 0.3380 & 0.8097 & & & \\
\hline SI & 0.2830 & 0.2610 & 0.7520 & & \\
\hline FC & 0.0710 & 0.0630 & 0.0730 & 0.7538 & \\
\hline BI & 0.4150 & 03930 & 0.3690 & 0.0930 & 0.7977 \\
\hline
\end{tabular}

The model test is then performed using confirmatory factor analysis (CFA). The CFA test shows chi-squared value of 1,405 , probability value 0.000 , RMSEA value 0,052 , GFI value 0,842, AGFI value 0,806, TLI 0,952 and CFI 0,958. From the results can be concluded that the model has a good suitability. The results of the CFA test are shown in Table 4. 
Table 4. Criteria model fit

\begin{tabular}{|l|c|r|l|}
\hline $\begin{array}{c}\text { The } \\
\text { goodness } \\
\text { of fit index }\end{array}$ & $\begin{array}{c}\text { Cut off } \\
\text { value }\end{array}$ & $\begin{array}{c}\text { Research } \\
\text { model }\end{array}$ & Result \\
\hline $\begin{array}{l}\text { Significant } \\
\text { Probability }\end{array}$ & $\geq 0.05$ & 0.000 & Poor fit \\
\hline Chi-square & $<5.00$ & 1.405 & Good fit \\
\hline RMSEA & $\leq 0.08$ & 0.052 & Good fit \\
\hline AGFI & $\geq 0.80$ & 0.806 & Good fit \\
\hline GFI & $\geq 0.90$ & 0.842 & Marginal fit \\
\hline TLI & $\geq 0.90$ & 0.952 & Good fit \\
\hline GFI & $\geq 0.90$ & 0.958 & Good fit \\
\hline
\end{tabular}

\section{Structural Model Estimation}

After testing the fit model criteria showing that overall showed a good level of conformity, then a theoretical hypothesis was tested. The test was conducted to determine the relationship between latent construction through SEM technique on AMOS software. The list of the path coefficients and their significance and hypothesis testing results is shown in table 5 .

Table 5. Hypothesis testing results

\begin{tabular}{|l|r|r|r|r|c|}
\hline & Estimate & \multicolumn{1}{|c|}{ SE } & \multicolumn{1}{c|}{ CR } & P & Result \\
\hline PE $\rightarrow$ BI & 0.367 & 0.116 & 3.151 & 0.002 & Yes \\
\hline EE $\rightarrow$ BI & 0.174 & 0.083 & 2.113 & 0.035 & Yes \\
\hline SI $\rightarrow$ BI & 0.726 & 0.13 & 5.57 & $* * *$ & Yes \\
\hline FC $\rightarrow$ BI & 0.01 & 0.052 & 0.189 & 0.85 & No \\
\hline
\end{tabular}

From the data processing, it is known that the value of $C R$ shows the value of 1.96 and the value of $P$ below 0.05 so it can be said that 3 hypotheses have an influence, and one hypothesis has no significant effect because the $\mathrm{P}$ value is more than 0.05 . The results show that performance expectancy, effort expectancy, and social influence have a positive effect on behavioral intentions. Effort expectancy $(p=0.002)$ has a greater effect than performance expectation $(p=0.035)$. The social influence $(p=0,000)$ also has a positive effect. Facilitation conditions have a value of $p$ $=0.850$ which shows a $\mathrm{P}$ value above 0.05 , which means that the facilitation conditions have no positive effect on behavioral intent.
Venkatesh (2003) explains that facilitating conditions are cost and system availability. According to Lin et al, facilitating conditions and good infrastructure can facilitate the use of the system.

\section{Discussions}

The results show that performance expectation has a positive effect using e-tilang. E-tilang is useful in work because it can improve performance. The results of this study support the research of Lin et al (2010), which says using online systems can help improve performance. Usefulness is useful for traffic police because e-tilang can be used anywhere and anytime. The perceived benefits have described a trust to use the system in improving performance. The results showed that e-tilang use can improve service to the public.

The results showed effort expectancy positively influences behavioral intentions in using e-tilang. Traffic cops say e-tilang is easy to learn. The level of ease is very influential in using the system. Construct This means an important factor in e-tilang adoption. E-tilang also provides an easy user interface. These results indicate that ease of use in e-tilang can improve performance and expected effort. Etilang can reduce illegal levies with good results. The results of this study support some previous research (Bagozzi \& Yi 1988; Alshehri 2012; Rehman et al. 2012; Verdegem \& Verleye 2009).

Social influences also have a positive effect in using e-tilang. People who are important to traffic police have a big influence on the use of e-tilang. Director of traffic directs traffic police to use e-tilang. The use of e-tilang is also influenced by other co-workers. This supports Barua (2012) research, which says users are likely to comply with applicable regulations. Liu et al. (2014) also revealed that a significant social influence on the continuation of the intention of using mobile services. 
The study states that the facility does not affect the intention to use e-tilang. The condition of Police Facilitation in Bengkulu is still inadequate. organizations do not have special personnel if electronic tilang have problems. According to Ajzen (1991), facilitating conditions can act as a proxy for controlling the direct behavior in using the system. traffic police still use manual tilang, so it is less effective. From the survey results are also known to the Internet network is sometimes a constraint. A favorable facilitation condition can increase the user to use e-tilang. Lindsay et al (2011) demonstrates easy and fast technology services that can rapidly improve the police ability to solve problems.

\section{Conclusions}

This study examines the factors affecting acceptance and use of e-tilang issued by the Indonesian National Police. Using the UTAUT model, this study shows that almost all the variables used in the method positively affects behavioral intentions in using e-tilang, such as work expectation, performance expectation, and social influence positively affects behavioral intentions in using e-tilang. For the construct of facilitation conditions, the results do not positively affect behavioral intentions in using e-tilang. This is because there are still inadequate facilities within the organization. Therefore, facilitation conditions should be improved to improve more effective services.

This study is also important steps to improve e-tilang services in the future, especially improving facilities conditions by the Police of the Republic of Indonesia in support of such e-tilang, such as facilities handphone and other internet devices. The more complete facilities and facilities provided to traffic police, the intention to use e-tilang will also be higher.

\section{Limitations}

This study has limitations because it only uses the main construction of the UTAUT model and has not included moderating effects (age, gender, and experience). Furthermore, the researchers only tested the acceptance of etilang at the traffic police organization.

\section{Acknowledgment}

We would like to thank the lecturers and colleagues of Master of Informatics Engineering Universitas Atma Jaya Yogyakarta, Yogyakarta, Indonesia who has helped in this research. We also thank the traffic police in Bengkulu who has given permission to study there.

\section{References}

Ajzen, I., 1991. The theory of planned behavior. Organizational Behavior and Human Decision Processes, 50, pp.179-211.

Akhtar Shareef, M. et al., 2014. Factors affecting citizen adoption of transactional electronic government. Journal of Enterprise Information Management, 27(4), pp.385-401.

Alshehri, M.A., 2012. Using the UTAUT Model to Determine Factors Affecting Acceptance and Use of E-government Services in the Kingdom of Saudi Arabia. , pp.1-264.

Azam, M.S., 2015. E-Services Adoption: Processes by Firms in Developing Nations. Advances in Business Marketing and Purchasing, 23, pp.7290. A

Bagozzi, R.P. \& Yi, Y., 1988. On the evaluation of structural equation models. Journal of the Academy of Marketing Science, 16(1), pp.74-94.

Barua, M., 2012. E-Governance Adoption in Government Organization of India. International Journal of Managing Public Sector Information and Communication Technologies, 3(1), pp.1-20.

Bates, L., Darvell, M.J. \& Watson, B., 2017. Young and unaffected by road policing strategies: Using deterrence theory to explain provisional drivers compliance. Australian \& New Zealand Journal of Criminology, 50(1), pp.23-38.

Bates, L.J. et al., 2014. Factors contributing to crashes among young drivers. Sultan Qaboos University Medical Journal, 14(3), pp.297-305.

Carter, L. \& Bélanger, F., 2005. The utilization of egovernment services: Citizen trust, innovation and 
acceptance factors. Information Systems Journal, 15(1), pp.5-25.

Chang, C.-C., 2013. Library mobile applications in university libraries. Library Hi Tech, 31(3), pp.478-492.

Hair, J.. et al., 2006. Multivariate data analysis.

Kayani, M.B. et al., 2011. Analyzing Barriers to eGovernment Implementation in Pakistan. International Journal for Infonomics, 4(3), pp.494-500.

Kumar, Al.A.A.A.A.K.F.V., 2016. E-government adoption and user's satisfaction: an empirical investigation. EuroMed Journal of Business, 11(1).

Lau, E.T.J.L., 2016. Behavioral intention to adopt mobile banking among the millennial generation. , 17(1).

Legohérel, D.K.R.L.A.B.P., 2013. Re-examining perceived usefulness and ease of use in online booking: The case of Hong Kong online users. International Journal of Contemporary Hospitality Management, 27(2), pp.185-198.

Lin, W.-B., Wang, M.-K. \& Hwang, K.P., 2010. The combined model of influencing online consumer behavior. Expert Systems with Applications, 37(4), pp.3236-3247.

Lindsay, R., Jackson, T.W. \& Cooke, L., 2011. Adapted technology acceptance model for mobile policing. Journal of Systems and Information Technology, 13(4), pp.389-407.

Liu, Y. et al., 2014. An empirical investigation of mobile government adoption in rural China: A case study in Zhejiang province. Government Information Quarterly, 31(3), pp.432-442.

MacCallum, R.C., Browne, M.W. \& Sugawara, H.M., 1996. Power analysis and determination of sample size for covariance structure modeling. Psychological Methods, 1(2), pp.130-149.

Madden, T., Ellen, P. \& Ajzen, I., 1992. A Comparison of the Theory of Planned Behavior and the Theory of Reasoned Action. Personality and social psychology Bulletin, 18(1), pp.3-9.

Mustonen-Ollila, E. \& Lyytinen, K., 2003. Why organizations adopt information system process innovations: a longitudinal study using Diffusion of Innovation theory. Info Systems J, 13, pp.275297.

Raja Yusof, R.J., Qazi, A. \& Inayat, I., 2017. Student real-time visualization system in the classroom using RFID based on UTAUT model. International Journal of Information and
Learning Technology, 34(3), pp.274-288.

Raman, A. et al., 2014. Technology acceptance on smart board among teachers in Terengganu using UTAUT model. Asian Social Science, 10(11), pp.84-91.

Rehman, M., Esichaikul, V. \& Kamal, M., 2012. Factors influencing e-government adoption in Pakistan. Transforming Government: People, Process, and Policy, 6(3), pp.258-282.

Verdegem, P. \& Verleye, G., 2009. User-centered EGovernment in practice: A comprehensive model for measuring user satisfaction. Government Information Quarterly, 26(3), pp.487-497.

Viswanath Venkatesh, Michael G. Morris, G.B.D. and F.D.D.R. et al., 2003. User Acceptance of Information Technology: Toward a Unified View. MIS Quarterly, 27(3), pp.425-478.

Williams, M., Rana, N. \& Dwivedi, Y., 2015. The unified theory of acceptance and use of technology (UTAUT): a literature review. 


\section{ATTACHMENT}

\section{MODEL}

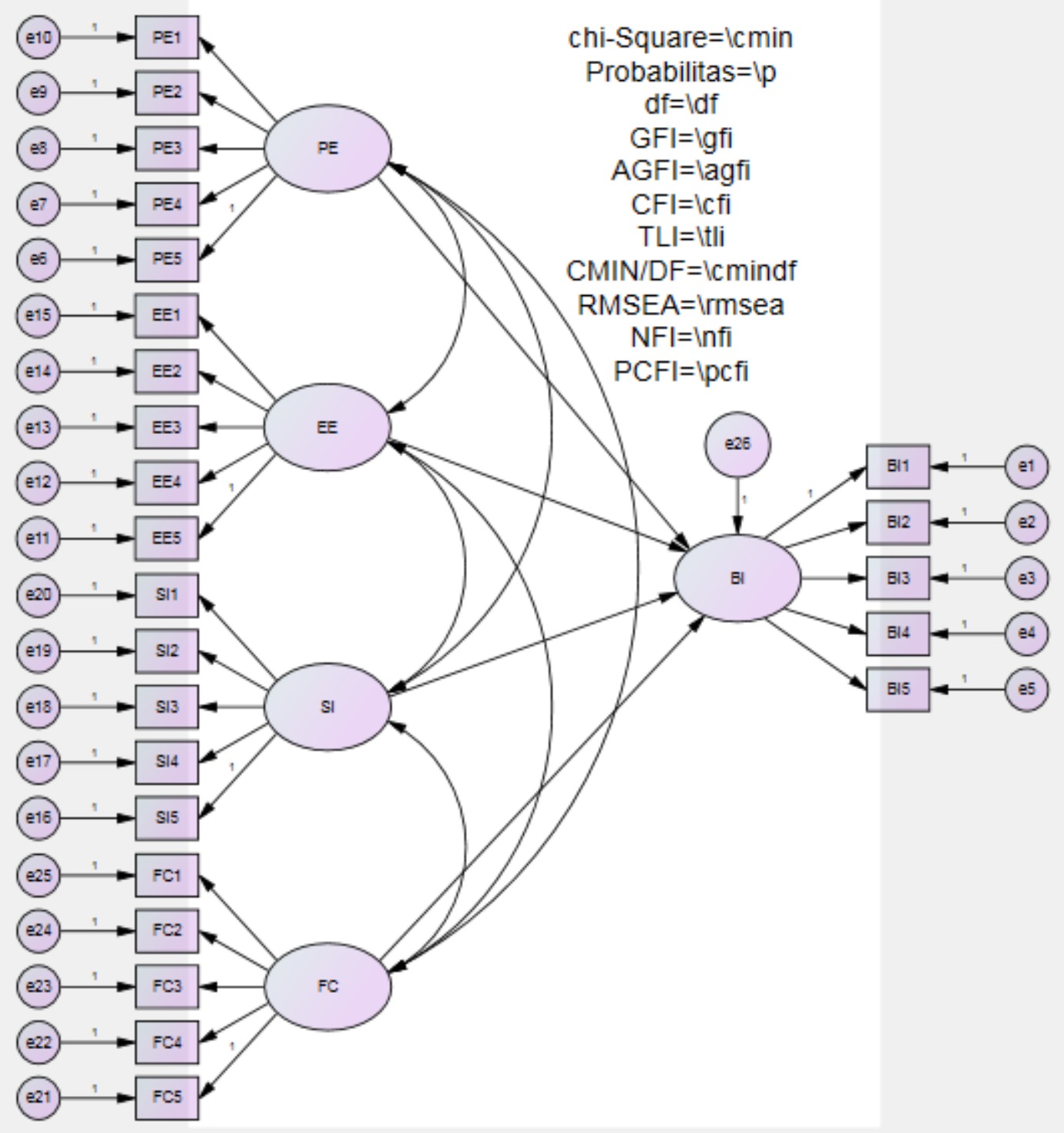




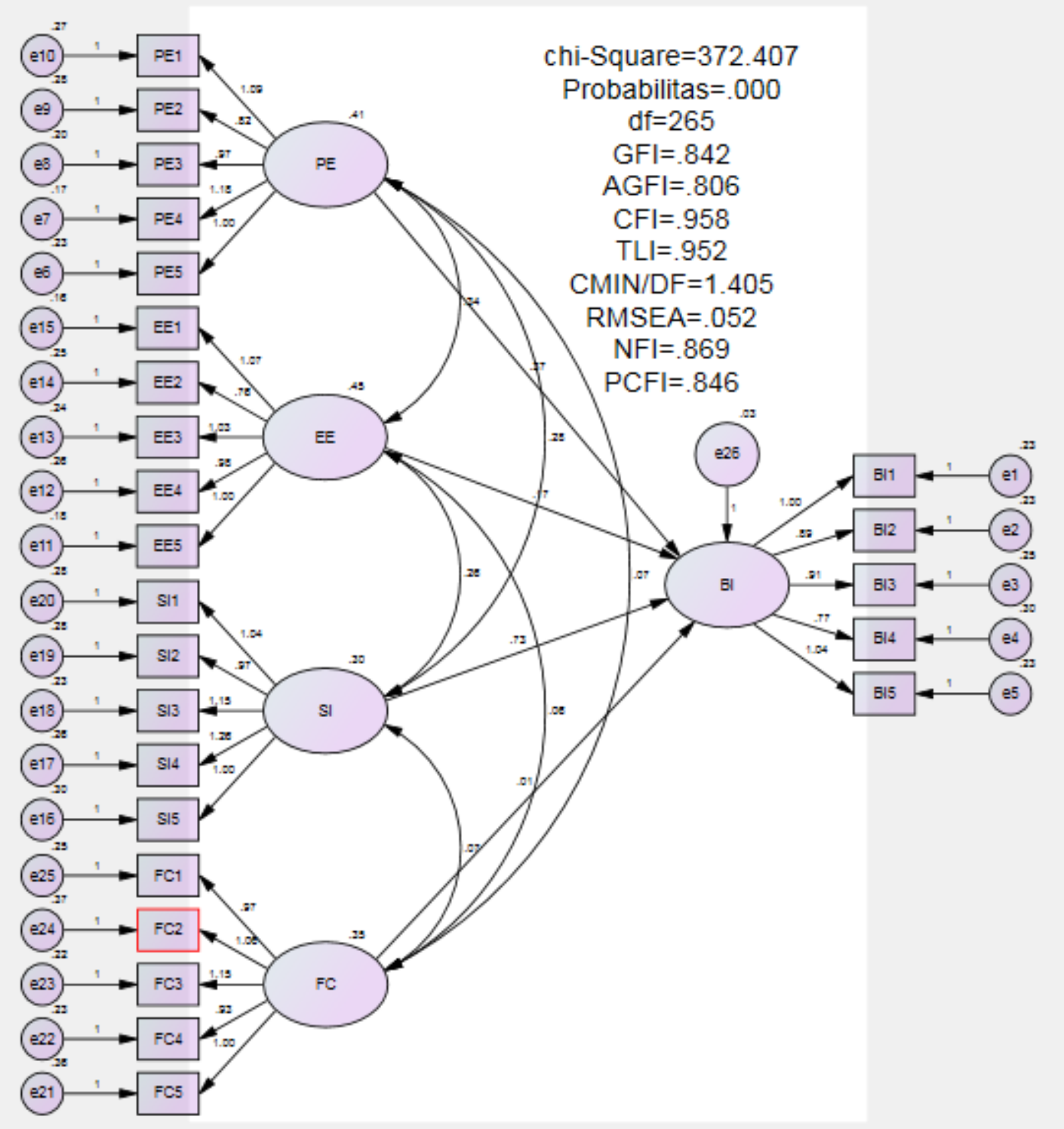




\section{DEGREE OF FREEDOM}

Computation of degrees of freedom (Default model)

Number of distinct sample moments: 325

Number of distinct parameters to be estimated: $\quad 60$

Degrees of freedom (325 - 60): 265

\section{NORMALITAS TEST}

Assessment of normality (Group number 1)

\begin{tabular}{|c|rrrrrr|}
\hline Variable & Min & max & skew & c.r. & kurtosis & c.r. \\
\hline FC1 & 1.000 & 5.000 & -.327 & -1.645 & -.004 & -.011 \\
FC2 & 1.000 & 5.000 & -.272 & -1.369 & -.430 & -1.082 \\
FC3 & 1.000 & 5.000 & .184 & .925 & -.301 & -.758 \\
FC4 & 1.000 & 5.000 & -.264 & -1.330 & .020 & .051 \\
FC5 & 1.000 & 5.000 & -.122 & -.616 & .140 & .353 \\
SI1 & 2.000 & 5.000 & .127 & .641 & -.519 & -1.305 \\
SI2 & 2.000 & 5.000 & -.162 & -.816 & -.296 & -.746 \\
SI3 & 2.000 & 5.000 & .306 & 1.540 & -.931 & -2.343 \\
SI4 & 2.000 & 5.000 & .217 & 1.093 & -.831 & -2.091 \\
SI5 & 2.000 & 5.000 & .055 & .277 & -.433 & -1.089 \\
EE1 & 2.000 & 5.000 & .205 & 1.032 & -1.000 & -2.517 \\
EE2 & 2.000 & 5.000 & -.138 & -.692 & -.263 & -.661 \\
EE3 & 2.000 & 5.000 & -.053 & -.267 & -1.024 & -2.577 \\
EE4 & 2.000 & 5.000 & -.116 & -.586 & -.789 & -1.985 \\
EE5 & 2.000 & 5.000 & .165 & .829 & -.765 & -1.926 \\
PE1 & 2.000 & 5.000 & .044 & .224 & -.914 & -2.300 \\
PE2 & 2.000 & 5.000 & .111 & .560 & -.993 & -2.500 \\
PE3 & 2.000 & 5.000 & -.083 & -.415 & -.393 & -.990 \\
PE4 & 2.000 & 5.000 & .150 & .754 & -.767 & -1.930 \\
PE5 & 2.000 & 5.000 & .279 & 1.405 & -.639 & -1.609 \\
BI5 & 2.000 & 5.000 & .166 & .834 & -.890 & -2.239 \\
BI4 & 2.000 & 5.000 & -.151 & -.758 & -.450 & -1.132 \\
BI3 & 2.000 & 5.000 & .042 & .212 & -.679 & -1.709 \\
BI2 & 2.000 & 5.000 & .449 & 2.260 & -.933 & -2.348 \\
BI1 & 2.000 & 5.000 & .048 & .242 & -.737 & -1.856 \\
Multivariate & & & & & -6.881 & -1.155 \\
\hline & & & & & & \\
\hline
\end{tabular}




\section{OUTLIER TESTING}

Observations farthest from the centroid (Mahalanobis distance) (Group number 1)

\begin{tabular}{|c|c|c|c|}
\hline Observation number & Mahalanobis d-squared & $\mathrm{p} 1$ & $\mathrm{p} 2$ \\
\hline 69 & 46.178 & .006 & .607 \\
\hline 89 & 42.882 & .014 & .645 \\
\hline 56 & 42.496 & .016 & .435 \\
\hline 80 & 39.374 & .034 & .758 \\
\hline 102 & 38.096 & .045 & .822 \\
\hline 132 & 36.888 & .059 & .891 \\
\hline 95 & 36.266 & .068 & .895 \\
\hline 85 & 35.973 & .072 & .863 \\
\hline 123 & 35.901 & .073 & .788 \\
\hline 151 & 34.554 & .097 & .929 \\
\hline 79 & 34.415 & .099 & .898 \\
\hline 58 & 33.824 & .112 & .927 \\
\hline 121 & 33.532 & .118 & .921 \\
\hline 146 & 33.007 & .131 & .944 \\
\hline 104 & 32.815 & .136 & .932 \\
\hline 131 & 32.494 & .144 & .936 \\
\hline 48 & 32.466 & .145 & .903 \\
\hline 54 & 32.418 & .146 & .863 \\
\hline 42 & 32.327 & .149 & .825 \\
\hline 111 & 32.206 & .152 & .791 \\
\hline 136 & 32.195 & .152 & .721 \\
\hline 64 & 32.172 & .153 & .647 \\
\hline 33 & 31.933 & .160 & .648 \\
\hline 130 & 31.464 & .174 & .732 \\
\hline 51 & 31.255 & .181 & .730 \\
\hline 76 & 31.043 & .188 & .730 \\
\hline 22 & 30.708 & .199 & .773 \\
\hline 144 & 30.237 & .216 & .851 \\
\hline 98 & 29.633 & .238 & .932 \\
\hline 119 & 29.344 & .250 & .947 \\
\hline 32 & 29.109 & .259 & .954 \\
\hline 6 & 28.968 & .265 & .950 \\
\hline 112 & 28.577 & .282 & .972 \\
\hline 149 & 28.386 & .290 & .974 \\
\hline 66 & 28.378 & .291 & .961 \\
\hline 82 & 28.141 & .301 & .968 \\
\hline 7 & 28.041 & .306 & .963 \\
\hline 50 & 28.015 & .307 & .949 \\
\hline 19 & 27.860 & .314 & .950 \\
\hline 2 & 27.844 & .315 & .931 \\
\hline 55 & 27.711 & .321 & .928 \\
\hline 71 & 27.699 & .322 & .903 \\
\hline 28 & 27.523 & .330 & .909 \\
\hline 41 & 27.510 & .331 & .880 \\
\hline
\end{tabular}


(JPMNT) Journal of Process Management - New Technologies, International Vol. 6, No 2, 2018.

\begin{tabular}{|c|c|c|c|}
\hline Observation number & Mahalanobis d-squared & p1 & $\mathrm{p} 2$ \\
\hline 11 & 27.378 & .337 & .878 \\
\hline 86 & 27.366 & .338 & .842 \\
\hline 35 & 27.223 & .345 & .844 \\
\hline 43 & 27.101 & .351 & .839 \\
\hline 40 & 26.810 & .365 & .883 \\
\hline 113 & 26.681 & .372 & .882 \\
\hline 84 & 26.668 & .373 & .849 \\
\hline 143 & 26.639 & .374 & .816 \\
\hline 93 & 26.510 & .381 & .815 \\
\hline 142 & 26.458 & .383 & .787 \\
\hline 12 & 26.331 & .390 & .787 \\
\hline 63 & 26.317 & .391 & .741 \\
\hline 137 & 25.894 & .413 & .851 \\
\hline 90 & 25.822 & .417 & .834 \\
\hline 31 & 25.682 & .425 & .840 \\
\hline 110 & 25.646 & .427 & .810 \\
\hline 21 & 25.531 & .433 & .807 \\
\hline 127 & 25.455 & .437 & .790 \\
\hline 34 & 25.384 & .441 & .770 \\
\hline 108 & 25.254 & .448 & .775 \\
\hline 60 & 25.146 & .454 & .770 \\
\hline 1 & 25.018 & .461 & .774 \\
\hline 122 & 24.797 & .474 & .815 \\
\hline 10 & 24.773 & .475 & .778 \\
\hline 100 & 24.719 & .478 & .752 \\
\hline 150 & 24.716 & .478 & 699 \\
\hline 145 & 24.290 & .503 & .831 \\
\hline 116 & 24.241 & .505 & .807 \\
\hline 148 & 24.188 & .509 & .782 \\
\hline 135 & 24.026 & .518 & .801 \\
\hline 125 & 23.933 & .523 & .793 \\
\hline 17 & 23.928 & .524 & .746 \\
\hline 120 & 23.861 & .527 & .725 \\
\hline 25 & 23.630 & .541 & .778 \\
\hline 140 & 23.448 & .551 & .807 \\
\hline 109 & 23.444 & .552 & .762 \\
\hline 37 & 23.404 & .554 & .728 \\
\hline 129 & 23.365 & .556 & .692 \\
\hline 78 & 23.315 & .559 & .659 \\
\hline 70 & 23.246 & .563 & .636 \\
\hline 14 & 23.164 & .568 & .619 \\
\hline 15 & 23.132 & .570 & .574 \\
\hline 16 & 23.057 & .574 & .553 \\
\hline 3 & 22.936 & .581 & .558 \\
\hline 65 & 22.877 & .585 & .527 \\
\hline 8 & 22.852 & .586 & .476 \\
\hline 67 & 22.776 & .591 & .455 \\
\hline 96 & 22.739 & .593 & .411 \\
\hline
\end{tabular}


(JPMNT) Journal of Process Management - New Technologies, International

Vol. 6, No 2, 2018.

\begin{tabular}{|r|rrr|}
\hline Observation number & Mahalanobis d-squared & $\mathrm{p} 1$ & $\mathrm{p} 2$ \\
\hline 49 & 22.703 & .595 & .368 \\
4 & 22.549 & .604 & .390 \\
88 & 22.318 & .617 & .458 \\
99 & 22.209 & .624 & .456 \\
114 & 22.184 & .625 & .404 \\
74 & 22.130 & .628 & .371 \\
62 & 22.118 & .629 & .315 \\
46 & 22.099 & .630 & .267 \\
\hline
\end{tabular}

HYPOTHESIS TESTING

Regression Weights: (Group number 1 - Default model)

\begin{tabular}{|c|c|c|c|c|c|c|c|}
\hline & & & Estimate & S.E. & C.R. & $\mathrm{P}$ & Label \\
\hline & $<---$ & $\mathrm{PE}$ & .367 & .116 & 3.151 & .002 & par_27 \\
\hline BI & $<---$ & $\mathrm{EE}$ & .174 & .083 & 2.113 & .035 & par_28 \\
\hline BI & $<---$ & SI & .726 & .130 & 5.570 & $* * *$ & par_29 \\
\hline BI & $<---$ & $\mathrm{FC}$ & .010 & .052 & .189 & .850 & par_30 \\
\hline BI1 & $<---$ & $\mathrm{BI}$ & 1.000 & & & & \\
\hline $\mathrm{BI} 2$ & $<---$ & BI & .893 & .076 & 11.761 & $* * *$ & par_1 \\
\hline $\mathrm{BI} 3$ & $<---$ & BI & .910 & .078 & 11.613 & $* * *$ & par_2 \\
\hline BI4 & $<---$ & $\mathrm{BI}$ & .773 & .078 & 9.887 & $* * *$ & par_3 \\
\hline BI5 & $<---$ & $\mathrm{BI}$ & 1.040 & .081 & 12.896 & $* * *$ & par_4 \\
\hline PE5 & $<---$ & $\mathrm{PE}$ & 1.000 & & & & \\
\hline PE4 & $<---$ & PE & 1.178 & .094 & 12.577 & $* * *$ & par_5 \\
\hline PE3 & $<---$ & PE & .968 & .086 & 11.191 & $* * *$ & par_6 \\
\hline PE2 & $<---$ & $\mathrm{PE}$ & .819 & .088 & 9.288 & $* * *$ & par_7 \\
\hline PE1 & $<---$ & PE & 1.086 & .099 & 11.023 & $* * *$ & par_8 \\
\hline EE5 & $<---$ & $\mathrm{EE}$ & 1.000 & & & & \\
\hline $\mathrm{EE} 4$ & $<---$ & $\mathrm{EE}$ & .978 & .086 & 11.396 & $* * *$ & par_9 \\
\hline EE3 & $<---$ & $\mathrm{EE}$ & 1.035 & .086 & 11.972 & $* * *$ & par_10 \\
\hline EE2 & $<---$ & $\mathrm{EE}$ & .760 & .076 & 10.005 & $* * *$ & par_11 \\
\hline EE1 & $<---$ & $\mathrm{EE}$ & 1.071 & .078 & 13.723 & $* * *$ & par_12 \\
\hline SI5 & $<---$ & SI & 1.000 & & & & \\
\hline SI4 & $<---$ & SI & 1.255 & .134 & 9.345 & $* * *$ & par_13 \\
\hline $\mathrm{SI} 3$ & $<---$ & SI & 1.147 & .125 & 9.204 & $* * *$ & par_14 \\
\hline $\mathrm{SI} 2$ & $<---$ & SI & .970 & .118 & 8.226 & $* * *$ & par_15 \\
\hline SI1 & $<---$ & SI & 1.036 & .123 & 8.438 & $* * *$ & par_16 \\
\hline FC5 & $<---$ & $\mathrm{FC}$ & 1.000 & & & & \\
\hline $\mathrm{FC} 4$ & $<---$ & $\mathrm{FC}$ & .935 & .116 & 8.026 & $* * *$ & par_17 \\
\hline FC3 & $<---$ & $\mathrm{FC}$ & 1.147 & .135 & 8.509 & $* * *$ & par_18 \\
\hline $\mathrm{FC} 2$ & $<---$ & $\mathrm{FC}$ & 1.063 & .128 & 8.295 & $* * *$ & par_19 \\
\hline $\mathrm{FC} 1$ & $<---$ & $\mathrm{FC}$ & .972 & .117 & 8.276 & $* * *$ & par_20 \\
\hline
\end{tabular}

